\title{
Patents, healthcare and engaged shareholders: a pathway to encourage socially responsible patent use?
}

\author{
Aisling McMahon* (D) and Edana Richardson ${ }^{\dagger}$ (if \\ Department of Law, Maynooth University, Ireland \\ *Corresponding author email: aisling.mcmahon@mu.ie
}

(Accepted 23 August 2021)

\begin{abstract}
This paper focuses on the drivers steering companies' behaviour over uses of patented health technologies, taking Covid-19 as a case study. Global equitable access to health technologies is vital to bringing the pandemic under control. Reflecting this, global mechanisms for rightsholders to share intellectual property rights, data and know-how over such health technologies have been developed. Yet, to date, there is limited support from corporate rightsholders for such mechanisms. Instead, health technologies have been licensed largely based on bilateral deals, with vast global inequalities emerging. Given the traditional focus within company law on prioritising shareholders' short-term financial value, we argue that it is unsurprising that many corporate rightsholders adopt a protectionist approach to patents, even in the face of health crises. However, we argue that the tide may now be starting to shift, catalysed by an emergence of engaged shareholders petitioning for socially responsible corporate behaviour, including for uses of intellectual property over health technologies in a manner that more clearly aligns with public interests. If harnessed and encouraged, such engaged shareholder behaviour could present an opportunity to reframe the conception of shareholder value towards one that considers a longterm sustainable approach and ultimately to shift corporate behaviour around uses of intellectual property over health technologies to take public interests into account.
\end{abstract}

Keywords: patent law; corporate decision-making; engaged shareholders; licensing of health technologies; access to medicines; Covid-19

\section{Introduction}

The Covid-19 pandemic continues to have significant health, economic and social consequences globally. A key element to managing, and ultimately bringing the pandemic under control, is delivering affordable and global access to effective vaccines, diagnostics and medicines (together, 'health technologies'). ${ }^{1}$ Accordingly, this has raised important questions around strategies for ensuring that access to health technologies is available on an equitable basis globally. Patents and other intellectual property rights play an important role here as they give the holder of those rights (the 'rightsholder') the right to exclude others from using the protected intellectual property, such as patented technology. This allows rightsholders to control who can access patented technologies, and on what terms, for the duration of the

\footnotetext{
${ }^{\dagger}$ The authors would like to thank Dr Cliodhna Murphy and Jon Webb for their helpful comments on earlier drafts of this paper. The authors also presented an earlier version of this paper at the Society for the Advancement of Socio-Economics (SASE) conference 2021, and are grateful to the attendees for their helpful comments. The usual disclaimer applies. The information presented is correct at time of writing, June 2021.

${ }^{1}$ Oxfam 'Campaigners warn that 9 out of 10 people in poor countries are set to miss out on Covid-19 vaccine next year' (9 December 2020), available at https://www.oxfam.org/en/press-releases/campaigners-warn-9-out-10-people-poor-countriesare-set-miss-out-covid-19-vaccine.

(C) The Author(s), 2021. Published by Cambridge University Press on behalf of The Society of Legal Scholars. This is an Open Access article, distributed under the terms of the Creative Commons Attribution licence (https://creativecommons.org/licenses/by/4.0/), which permits unrestricted re-use, distribution, and reproduction in any medium, provided the original work is properly cited.
} 
patent. Given that many rightsholders within the health sector are companies, the role of such companies in using intellectual property rights is a key factor in determining how access to healthcare is delivered. This issue forms the focus of this paper. More specifically, this paper examines the main influences on companies as rightsholders that drive their decisions on licensing and enforcing patents over health technologies, ${ }^{2}$ and the extent to which such influences align with broader social interests in ensuring global healthcare access.

Corporate behaviour during health emergencies has raised significant concerns. As will be discussed, even during the Covid-19 pandemic some companies have used patents in a manner that could hinder access to essential health technologies. ${ }^{3}$ Concerns have arisen around the risk of rightsholders engaging in profiteering behaviour over Covid-19 health technologies, with significant implications, for example in the context of global vaccine access. ${ }^{4}$ Questions have also been raised around why, given the global emergency that Covid-19 presents, there is not greater sharing of intellectual property rights, regulatory data and know-how by companies over health technologies to scale up global production of those health technologies. ${ }^{5}$

This paper focuses on these timely and pressing issues. Taking Covid-19 as a case study, it specifically probes the overarching system steering companies' behaviour with respect to how they license and use their patents over health technologies. It argues that given the current broader legal and institutional contexts applicable, it is unsurprising that many corporate rightsholders have adopted protectionist approaches towards their intellectual property rights, including patents. Reflecting this, despite the health crisis, many companies remain reticent to engage with proposed models for the voluntary sharing of intellectual property rights and know-how to increase manufacture of Covid-19 health technologies. More specifically, we argue that under the current status quo: (1) company directors' duties are designed to favour maximising shareholder 'value', where value has traditionally been interpreted as financial value for shareholders; (2) human rights frameworks have limited teeth in imposing mandatory obligations on corporate entities in this context; and (3) measures for governments to interfere with rightsholders' discretion over patented technologies, such as via compulsory licensing, are often exceptionalised in practice. Such factors culminate to produce a system that is predisposed to encourage companies as rightsholders to act in a manner that facilitates the short-term financial benefits of shareholders, and arguably marginalises the broader public interests at stake.

However, one pathway to encourage change within the confines of the current system may now be strengthening, with examples of shareholders petitioning companies to incorporate longer-term interests and societal values within corporate decision-making. As will be demonstrated, several groups of shareholders have recently petitioned companies to consider the broader public interests at stake in corporates' decisions - including the impact of decision-making on access to healthcare. In such contexts, we argue there is growing nuance in how shareholder 'value' could be interpreted. This could be used to facilitate a

\footnotetext{
${ }^{2}$ In taking this focus, the paper recognises that other entities alongside companies, such as public entities, also operate within the health innovation landscape.

${ }^{3}$ See Médecins Sans Frontières (MSF) 'WTO Covid-19 TRIPS waiver proposal myths, realities and an opportunity for governments to protect access to lifesaving medical tools in a pandemic' (December 2020), available at https://msfaccess.org/sites/ default/files/2020-12/MSF-AC_COVID_IP_TRIPSWaiverMythsRealities_Dec2020.pdf.

${ }^{4}$ See MSF 'MSF Covid-19 action for access', available at https://msfaccess.org/covid-19-action; L Hooker and D Palumbo 'Covid vaccines: will drug companies make bumper profits?' BBC News (18 December 2020), available at https://www.bbc. com/news/business-55170756. For discussion about profiteering in the context of booster vaccine doses, see F Hassan et al 'Profiteering from vaccine inequity: a crime against humanity?' (2021) British Medical Journal, available at https:// www.bmj.com/content/374/bmj.n2027.

${ }^{5}$ Oxfam, above $\mathrm{n}$ 1. Indeed, given the lack of support for voluntary measures to share intellectual property rights related to Covid-19 health technologies, India and South Africa have proposed a temporary waiver to the TRIPS Agreement (defined below) that would temporarily suspend certain intellectual property obligations under TRIPS. This proposal is still under discussion at WTO level. As this is still at proposal stage, and as the paper's primary focus is how shareholder action within the confines of the current system can be supported and harnessed, we do not consider the waiver in detail here. For a detailed discussion of the waiver see S Thambisetty et al 'The TRIPS intellectual property waiver proposal: creating the right incentives in patent law and politics to end the Covid-19 pandemic' (24 May 2021), LSE Legal Studies Working Paper No 06/2021, available at https://ssrn.com/abstract $=3851737$.
} 
move away from a focus purely on profit maximisation to a more holistic approach under the established and prevailing shareholder primacy model. Such developments could be harnessed to encourage companies to pay greater attention to, and engage with, broader public interests when licensing and enforcing patents in the healthcare context. In effect, we argue that shareholders are - and could be empowered to continue - internally pushing for a recognition by company directors that aligning the licensing of health technologies with public interest in access to essential health technologies is in the longer-term interests of shareholders and is of value to them. This shareholder engagement could be harnessed as a pragmatic mechanism to encourage more socially responsible and sustainable approaches to the licensing of health technologies. Reflecting this, we will outline four strategies to encourage and mandate a broader systemic change around how health technologies are licensed, which aim to empower and inform shareholders to act, encourage the public to scrutinise corporate behaviour and give company directors impetus and commercial incentive to act. Together, these strategies can further support and encourage this trend of shareholder engagement in the health-technology sector.

The arguments made in this paper have important policy-facing applications for healthcare, corporate decision-making and pharmaceutical innovation. The arguments made also have resonance in other contexts beyond healthcare, where access to patented technologies has significant implications for society (for example, in the context of access to environmental technologies to reduce emissions, or access to agricultural or sanitation technologies). ${ }^{6}$

The paper is structured as follows: Part 1 demonstrates the power of companies as rightsholders over access to and delivery of health technologies. Part 2 analyses corporate decision-making by setting it in the context of a broader company law framework. It outlines the shareholder primacy model and the approach in corporate decision-making of prioritising the short-term financial interests of shareholders above social interests, such as access to healthcare. However, Part 3 argues that there are indications that a change may be emerging, highlighting examples of shareholders actively petitioning for corporate decision-making to consider broader public interests (including during Covid-19). Part 4 outlines four key strategies that could be used to support such engaged shareholder activity and to thereby foster a more socially responsible approach to patent licensing for health technologies. The conclusion argues that, although companies still operate within a shareholder primacy model of corporate governance, the notion of 'value' within this model could be broadened, and engaged shareholder activity could be used to support this change. We now have an opportunity to embed a more socially responsible approach to licensing and use of patents over health technologies by companies. Given the significant health consequences at stake, it is incumbent upon us to empower such engaged shareholders and to thereby seize this opportunity to achieve change.

This paper focuses primarily on legal principles and applicable international laws as they apply in the UK. It does this for two reasons. First, companies involved in the health sector are incorporated in countries across the world - by using the legal situation as it applies in the UK as a case study, ${ }^{7}$ we can map the legal backdrop applicable to companies incorporated and/or publicly traded in the UK that are involved in the development of health technologies. Yet the arguments made have broader resonance and give rise to insights on what pathways could be adopted in other countries to facilitate a more socially responsible licensing culture for patented health technologies. Secondly, while shareholder engagement with social issues is particularly evident in recent developments in the US, we are starting to see signs of similar engagement in the UK. However, the impact of this engagement on patent licensing for health technologies remains under-researched. This paper fills this gap by providing a comprehensive and novel analysis that considers the potential to harness engaged shareholder activity as part of a broader strategy to drive the consideration of societal interests in the use and licensing of

\footnotetext{
${ }^{6} \mathrm{C}$ Bradshaw 'The environmental business case and unenlightened shareholder value' (2012) 33(1) LS 141.

${ }^{7}$ This is a single outcome case study that research shows can be useful in identifying and examining factors relevant to a particular context: see TT Arvind and A McMahon 'Responsiveness and the role of rights in medical law: lessons from Montgomery' (2020) 28(3) Medical Law Review 445. See also J Gerring 'What is a case study and what is it good for?' (2004) 98 American Political Science Review 341; J Gerring 'Single-outcome studies: a methodological primer' (2006) 21 International Sociology 707.
} 
health-technology patents in the UK. In doing so, it provides an opportunity to consider how shareholder engagement may develop and how best it can be supported and facilitated in the UK context. ${ }^{8}$

\section{Patents and companies as rightsholders}

An examination of how patents over health technologies are used by companies highlights the significant effects patents can have on access to healthcare, ${ }^{9}$ and builds a case for why the framework and factors driving companies' decision-making (as rightsholders) play a critical role that warrants deeper consideration.

Before delving into the core arguments around patents, two points must be made. First, while this paper focuses on patent rights, we acknowledge that other intellectual property rights also have a significant impact on access to healthcare. ${ }^{10}$ This paper focuses on patents as a case study in this context, although such arguments may have resonance for uses of other intellectual property rights. Secondly, information not covered by intellectual property rights (such as know-how) also poses difficulties for access to health technologies, ${ }^{11}$ and similar considerations may be needed in the sharing of nonpatented confidential information required to produce these health technologies. ${ }^{12}$

\section{(a) The impact of patent use on access to and delivery of healthcare}

A patent is an intellectual property right that allows the rightsholder to exclude others from using the patented technology without the rightsholder's permission (license) for the duration of the patent (generally 20 years). All World Trade Organisation (WTO) members (164 states worldwide, including all EU Member States and the $\mathrm{UK}^{13}$ ) must make patents available for all fields of technology (including health technologies) under the Agreement on Trade-Related Aspects of Intellectual Property Rights (TRIPS). ${ }^{14}$ Accordingly, WTO members cannot refuse patents on health technologies, ${ }^{15}$ or introduce a blanket restriction on the application of intellectual property rights in emergency contexts (including Covid-19). ${ }^{16}$

This exclusionary nature of a patent gives rightsholders a private governance role over the patented health-technology ${ }^{17}$ as it allows the rightsholder to control who can gain access to the technology and

\footnotetext{
${ }^{8}$ For a discussion of applicable rules in the UK, US and Germany, see M Yan 'Shareholder control in the context of corporate social responsibility: a fundamental challenge to the modern corporate' (2020) 50(3) Hong Kong Law Journal 1057 at 1060-1061. See also LA Bebchuk and R Tallarita 'The illusory promise of stakeholder governance' (2020) 106 Cornell Law Review 91.

${ }^{9}$ See A McMahon 'Global equitable access to vaccines, medicines and diagnostics for Covid-19: the role of patents as private governance' (2020) 47(3) Journal of Medical Ethics 142.

${ }^{10}$ Such as trade secret protections: see D Levine 'Covid-19 should spark a re-examination of trade secrets' stranglehold on information' Stat News (10 July 2020), available at https://www.statnews.com/2020/07/10/covid-19-reexamine-trade-secretsinformation-stranglehold/; SE Crager 'Improving global access to new vaccines: intellectual property, technology transfer, and regulatory pathways' (2014) 104 American Journal of Public Health S414-S420.

${ }^{11}$ In some cases, sharing intellectual property rights alone will not be enough for rights-holders to facilitate others making biosimilar or generic versions of biologics or vaccines. In such cases, strategies to facilitate use of patented health technologies by others should also consider mandating the sharing of this additional information including know-how and regulatory data: WN Price et al 'Knowledge transfer for large-scale vaccine manufacturing' Science (13 August 2020), available at https://science.sciencemag.org/content/early/2020/08/12/science.abc9588/tab-article-info?versioned=true.

${ }^{12}$ See discussion in McMahon, above $\mathrm{n} 9$. See also Thambisetty et al., above $\mathrm{n} 5$.

${ }^{13}$ WTO 'Members and observers' (2021), available at https://www.wto.org/english/thewto_e/whatis_e/tif_e/org6_e.htm.

${ }^{14}$ TRIPS Agreement, Art 27.

${ }^{15}$ Some exclusions against patentability exist under Art 27 of the TRIPS Agreement, but these are limited in nature.

${ }^{16}$ There is currently a proposal to suspend intellectual property rights over technologies related to prevention, containment and treatment of Covid-19 at the WTO. However, this would be a modification to the existing system, and discussions are ongoing: WTO 'Members to continue discussion on proposal for temporary IP waiver in response to Covid-19' (10 December 2020), available at https://www.wto.org/english/news_e/news20_e/trip_10dec20_e.htm.

${ }^{17} \mathrm{~A}$ McMahon 'Biotechnology, health and patents as private governance tools: the good, the bad and the potential for ugly?' (2020) 18(3) Intellectual Property Quarterly 161.
} 
on what terms. For example, a rightsholder of a patented medicine can control who supplies, manufactures and sells that medicine - if they refuse others the permission to manufacture and/or supply the medicine, they can become the sole provider for the duration of the patent. This could limit supplies of a medicine (depending on the rightsholder's manufacturing capacity) and could potentially result in high prices being set. ${ }^{18}$ Ultimately, therefore, patents give rightsholders the potential to dictate who gets access to health technologies first. Where demand is not met by supply (as has been the case for Covid-19 vaccines), ${ }^{19}$ this can be highly problematic and is a key factor that has contributed to the inequitable global distribution of essential health technologies. Patents can also have a knock-on effect on other technologies that require access to a patented technology to operate, thereby affecting the downstream development and uses of dependent technologies.

\section{(b) Patents over health technologies and access to health}

The impact of pharmaceutical companies' use of patents over health technologies for access to healthcare was starkly demonstrated by the HIV/AIDS crisis in the $1990 \mathrm{~s}^{20}$ During that time, HIV/AIDS caused millions of deaths globally. ${ }^{21}$ Whilst treatments were available and could be used to save lives, for many (particularly in sub-Saharan Africa) such treatments were inaccessible. A key factor in this lack of access was the actions of pharmaceutical companies who, in their capacity as rightsholders, refused to license or sell patented HIV/AIDS treatments at prices low enough for developing countries to afford. Some companies also sought to block efforts by governments to amend patent laws to facilitate wider access to medicines - for example, in 1998 a group of 39 pharmaceutical companies started legal proceedings against the South African government after it sought to amend patent laws to make it easier to produce generic versions of HIV/AIDS medicines. $^{22}$

Amidst international backlash and civil society interventions, this legal action was dropped in April $2001^{23}$ and ultimately greater access to such patented treatments was achieved. However, millions of lives were lost due to lack of access to affordable medicines. In November 2001, following sustained activism, the Doha Declaration was signed. This declaration confirmed that the existing TRIPS Agreement ${ }^{24}$ had in-built flexibilities that could limit the application of intellectual property rights in specific circumstances where public health requires it. Following the Doha Declaration, TRIPS flexibilities including compulsory licensing (whereby if a rightsholder refuses to license their patented technology on reasonable terms, a state can issue a license to a third party over the patented technology) were used to deliver access to medicines in lower-income countries. ${ }^{25}$ In 2010, the Medicines Patent Pool was set up to facilitate voluntary mechanisms for the sharing of rights related to medicines for HIV/AIDS. ${ }^{26}$ Yet the legacy of this time demonstrates the power that companies as rightsholders have within the healthcare context. It also serves to highlight the priority placed by rightsholders on

\footnotetext{
${ }^{18}$ It is conceded that multiple patents or other intellectual property rights may apply over any one health-technology. The example given here, which focuses on one key rightsholder, is given for illustration only.

${ }^{19}$ McMahon, above n 9.

${ }^{20}$ See discussion in E't Hoen et al 'Driving a decade of change: HIV/AIDS, patents and access to medicines for all' (2011) 14(1) Journal of the International AIDS Society 14.

${ }^{21} \mathrm{~B}$ Gellman 'An unequal calculus of life and death; as millions perished in pandemic, firms debated access to drugs; players in the debate over drug availability and pricing' (2000) The Washington Post (A01), as cited ibid.

${ }^{22}$ D Halbert 'Moralized discourses: South Africa's intellectual property fight for access to AIDS drugs' (2002) 1(2) Seattle Journal for Social Justice Article 2; H Klug 'Access to medicines and the transformation of the South African state: exploring the interactions of legal and policy changes in health, intellectual property, trade, and competition law in the context of South Africa's HIV/AIDS pandemic' (2012) 37(2) Law \& Social Inquiry 297.

${ }^{23}$ 't Hoen, above $n 20$.

${ }^{24}$ DOHA WTO Declaration 2001 (TRIPS WT/MIN(01)/DEC/2, 20 November 2001), Declaration on the TRIPS agreement and public health.

${ }^{25}$ 't Hoen, above n 20.

${ }^{26}$ It has since expanded its remit to include other disease: see the MPP website at medicinespatentpool.org.
} 
enforcing and maintaining intellectual property rights over broader public interests, even during a public health emergency.

This potential for patents to be used by companies in a manner that can impede access to healthcare continues to this day, including recent controversies about uses of patents on Solvadi/Sofusivr for Hepatitis $C_{,}^{27}$ and access to vaccines for the human papillomavirus (HPV) against cervical cancers ${ }^{28}$ and the pneumococcal conjugate vaccine $(\mathrm{PCV})$ used against childhood pneumonia. ${ }^{29}$

\section{(c) Patents over health technologies: Covid-19}

The Covid-19 pandemic has brought issues with respect to intellectual property rights and access to healthcare into the spotlight. For instance, during the first phase of the pandemic a legal challenge was taken in the US by Labrador Diagnostics LLC (Labrador) against BioFire Diagnostics LLC (BioFire) alleging patent infringement by BioFire in its development of Covid-19 testing kits. ${ }^{30}$ This challenge was later dropped amidst media backlash, with Labrador stating that it would allow uses of its patent on a royalty-free basis to develop tests for Covid-19. ${ }^{31}$ However, decisions like this to take legal action reflect a prioritisation of intellectual property rights, even when the enforcement of such rights could potentially contradict the broader health interests at stake. We have also seen rightsholders agree to preferential supply deals with higher-income countries for priority access to Covid-19 vaccines. ${ }^{32}$ A vast global inequity of access to Covid-19 vaccines has emerged between higher and low/middle income countries, and, under predicted supply deals, 9 in 10 people in 67 low- to middle-income countries are not expected to gain access to Covid-19 vaccines in $2021 .^{33}$

This inequality in global access to health technologies is self-defeating for all countries who wish to control the pandemic - until all countries in the world have sufficient access to vaccines, there will be a risk of outbreaks re-emerging and of mutations of the virus developing that may be resistant to existing vaccines. ${ }^{34}$ Rightsholders could alleviate access issues by joining voluntary programmes to share intellectual property rights and data over Covid-19 health technologies ${ }^{35}$ (such as WHO's Covid-19

\footnotetext{
${ }^{27}$ E Sagonowsky 'Gilead's Sovaldi patient under fire again from MSF coalition, this time in Europe' Fierce Pharma (27 March 2017), available at https://www.fiercepharma.com/pharma/access-groups-join-together-european-assault-sovaldipatent; N Dearden 'Big Pharma's finest hour?' Open Democracy (10 January 2021), available at https://www.opendemocracy.net/en/opendemocracyuk/big-pharmas-finest-hour; L Kintada 'Compulsory licensing for hepatitis C medication in Malaysia’ Public Citizen (10 April 2019), available at https://www.citizen.org/news/compulsory-licensing-for-hepatitis-cmedication-in-malaysia/.

${ }^{28} \mathrm{C}$ Clendinen et al 'Manufacturing costs of HPV vaccines for developing countries' (2016) 34(48) Vaccine 5984.

${ }^{29}$ MSF A Fair Shot for Vaccine Affordability (2017, reprinted February 2018), available at https://msfaccess.org/fair-shotvaccine-affordability.

${ }^{30}$ McMahon, above n 9.

${ }^{31}$ DR Auth 'Covid-19 update: patent tights in the Covid-19 pandemic: how will industries and governments respond?' The National Law Review (27 March 2020), available at https://www.natlawreview.com/article/covid-19-update-patent-rightscovid-19-pandemic-how-will-industries-and-governments.

${ }^{32} \mathrm{D}$ Matthews 'Coronavirus: how countries aim to get the vaccine first by cutting opaque supply deals' The Conversation (27 July 2020), available at https://theconversation.com/coronavirus-how-countries-aim-to-get-the-vaccine-first-by-cuttingopaque-supply-deals-143366; AS Rutschman 'How "vaccine nationalism” could block vulnerable populations' access to Covid-19 vaccines' The Conversation (17 June 2020), available at https://theconversation.com/how-vaccine-nationalismcould-block-vulnerable-populations-access-to-covid-19-vaccines-140689.

${ }^{33}$ Oxfam, above n 1.

${ }^{34}$ As Dr Tedros Adhanom Ghebreyesus (WHO) noted: 'Vaccine nationalism is not just morally indefensible. It is epidemiologically self-defeating and clinically counterproductive': TA Ghebreyesus 'Vaccine nationalism harms everyone and protects no one' Foreign Policy (2 February 2021), available at https://foreignpolicy.com/2021/02/02/vaccine-nationalism-harmseveryone-and-protects-no-one/.

${ }^{35}$ For an overview of some proposals in this context, see JL Contreras et al 'Pledging intellectual property for Covid-19' (2020) 38(10) Nature Biotechnology 1146. See also S Geiger and A McMahon 'Too many cooks or too many recipes? An analysis of the institutional landscape and proliferation of proposals for global vaccine equity for Covid-19’ (2020) Working Papers 202108, Geary Institute, University College Dublin.
} 
Technology Access Pool (CTAP), ${ }^{36}$ a global mechanism to facilitate the sharing of intellectual property rights, data and know-how on health technologies). Yet, at the time of writing, no rightsholder of patents related to vaccines has contributed to CTAP. ${ }^{37}$

The rationale supporting the sharing of intellectual property in the Covid-19 context is also strengthened by the vast amounts of public funding that have been used to support Covid-19 health innovation, particularly in the vaccine context, de-risking much of the potential losses and costs of failures for pharmaceutical companies. ${ }^{38}$ Based on the foregoing, it is evident that even during one of the most significant global health crises of our time, there is still a continued promotion of a status quo approach by many companies in how they use and license patent rights over health technologies. There remains a prioritisation of commercial value over public interests. From a legal perspective, a question that arises is how this prioritisation is sustained by companies in the face of significant health implications, and the role that existing legal and voluntary frameworks play in facilitating this.

\section{Drivers of corporate decision-making: primacy of shareholders' profit}

The system for corporate decision-making on patents does not mandate corporate rightsholders to develop patent licensing or enforcement practices over patented health technologies in a manner that aligns with public health needs. Instead, as this section will demonstrate, from a company law perspective the duties of company directors lie primarily in increasing 'value' for shareholders. This notion of 'value' has traditionally been interpreted as financial value. Alongside this, avenues to encourage more socially responsible patent licensing practices by companies through reliance on arguments based on human rights have tended to lack teeth, and mechanisms within intellectual property law for states to intervene with rightsholders' decisions over patented technologies have been exceptionalised in practice. Accordingly, we argue that such factors combine to foster a system where companies are predisposed to make decisions related to the use of patents in a manner that prioritises shareholder profit. When considered within this broader legal and institutional context, the actions of companies discussed above - including the often-limited engagement by many companies with broader public interests at stake when they use patents over health technologies - are not only unsurprising but are entirely expected. Yet this does not mean that this approach is what should happen - if we want a better account for public health needs in this context, one change that is urgently needed is a re-evaluation of the system and drivers related to corporate decision-making.

\section{(a) Prioritising shareholders: financial value}

The question of in whose interests a company should be run has been the subject of debate for many years. ${ }^{39}$ The dominant view within company law theory (at least within the common law world) has been that of shareholder primacy. ${ }^{40}$ This approach provides that companies, as separate legal entities run by their directors, are first and foremost accountable to their shareholders - within the limits of the law they must act in those shareholders' interests above the interests of other parties. ${ }^{41}$ This legal duty to shareholders has commonly been framed as one that prioritises shareholders' financial

\footnotetext{
${ }^{36}$ WHO 'Commitments to share knowledge, intellectual property and data', available at https://www.who.int/emergencies/ diseases/novel-coronavirus-2019/global-research-on-novel-coronavirus-2019-ncov/covid-19-technology-access-pool.

${ }^{37}$ This is correct at the time of writing in June 2021.

${ }^{38}$ See generally M Hoecklin ' $€ 93$ billion spent by public sector on COVID vaccines and therapeutics in 11 months, research finds' (Health Policy Watch), available at https:/healthpolicy-watch.news/81038-2/.

${ }^{39}$ A Keay 'Tackling the issue of the corporate objective: an analysis of the United Kingdom's "enlightened shareholder value approach"' (2007) 29 Sydney Law Review 577 at 577.

${ }^{40}$ SS Kuo and B Means 'Corporate social responsibility after disaster' (2012) 89 Washington University Law Review 973 at 995; P Ireland 'Shareholder primacy and the distribution of wealth' (2015) 68(1) The Modern Law Review 49 at 49-50.

${ }^{41}$ Keay, above n 39 .
} 
interests. ${ }^{42}$ As a result, the idea of shareholder primacy provides that companies should be run in a way that maximises shareholder financial returns by optimising the company's market value. ${ }^{43}$ To achieve this, the powers exercisable by or on behalf of companies '... are necessarily and at all times exercisable only for the ... benefit of all the shareholders as their interest appears' ${ }^{44}$ Under this model, the interests of others who may be impacted by a company's actions and decisions must not be accounted for if to do so would undermine the company's primary responsibility to maximise its shareholders' returns. ${ }^{45}$ This in turn means that company directors, in making decisions related to the company's property and interests (including the protection of its intellectual property rights), must have in mind their duty to maximise financial returns for shareholders. Arguably, under this narrow construction of shareholder 'value', directors of companies holding patents are both legally required and institutionally predisposed to make decisions about the enforcement and licensing of patents in a manner that maximises financial returns for shareholders.

An alternative approach to company duties has also been proposed, namely, 'stakeholder theory'. According to this theory, companies should be run in a way that addresses the interests of a much wider range of stakeholders beyond just the company's shareholders. ${ }^{46}$ The concept of 'stakeholder' in this context is composed of interested parties 'who can affect or [be] affected by the achievement of the organization's objective'. ${ }^{47}$ While this might include those interacting directly with a company, such as its employees, customers and creditors, it could also be interpreted more broadly to include the environment, the community of participants in the sector(s) in which the company operates, and society generally. ${ }^{48}$ In the context of a company involved in the healthcare sector, notions of 'community' and 'society' are broad. They could conceivably include the need to account for the effect of corporate decision-making on the delivery of, and access to, healthcare and on the development of health research, each of which affects the community and society more generally. More specifically, patents in such contexts can have an impact on the interests of patients and individuals seeking access to healthcare, healthcare professionals delivering healthcare, and the scientific and health research community seeking to develop new health technologies. ${ }^{49}$

The stakeholder theory suggests that companies should focus on a range of goals beyond demonstrable shareholder financial profit. With respect to companies holding patents over health technologies, stakeholder theory could ground arguments in favour of such companies being required to incorporate broader social considerations in decision-making on the use and licensing of their patents. Yet despite this, the shareholder primacy model remains the prevailing approach in the corporate law framework of many countries, including the UK, the US, and Ireland. ${ }^{50}$ Legislation and business practice, therefore, continue to uphold the rule that companies should strive to maximise shareholder value, within the limits of the law. ${ }^{51}$

\footnotetext{
${ }^{42}$ D Millon 'Radical shareholder primacy' (2013) 10 University of St Thomas Law Journal 1013.

${ }^{43} \mathrm{C}$ Mayer 'Corporate governance, competition, and performance' (1997) 24(1) Journal of Law and Society 152 at 155.

${ }^{44}$ AA Berle 'Corporate powers as powers in trust' (1931) 44(7) Harvard Law Review 1049 (emphasis added). See also M Friedman 'The social responsibility of business is to increase profits' (September 1970) New York Times Magazine 33.

${ }^{45}$ Millon, above n 42, at 1013 .

${ }^{46}$ LA Stout 'New thinking on shareholder primacy' (2012) 2 Accounting, Economics, and Law [xix] at 2.

${ }^{47}$ RE Freeman Strategic Management: A Stakeholder Approach (Cambridge: Cambridge University Press, 2020) p 46.

${ }^{48}$ Keay, above $\mathrm{n} \mathrm{39}$, at 594; JJ du Plessis and A Rühmkorf 'New trends regarding sustainability and integrity reporting for companies: what protection do directors have?' (2015) 36(2) Company Lawyer 51 at 53; Bebchuk and Tallarita, above n 8 , at 93 .

${ }^{49} \mathrm{M}$ Min et al 'Should pharmaceutical companies engage in corporate social responsibility?' (2017) 36(1) Journal of Management Development 58 at 61 .

${ }^{50}$ See H Hansmann and R Kraakman 'The end of history for corporate law' (2001) 89 Georgetown Law Journal 439 at 468 , noting that 'The standard model has never been questioned for the vast majority of corporations. It dominates the law and governance of closely held corporations in every jurisdiction'.

${ }^{51}$ Ireland, above n 40 , at $49-50$.
} 


\section{(b) Companies' human rights obligations: lacking teeth}

In the absence of effective standards mandating socially responsible licensing practices by corporate rightsholders, some commentators have proposed reliance on companies' human rights obligations to call for greater consideration to be given to stakeholders impacted by rightsholders' decisions. On this basis, the human right to health ${ }^{52}$ has been cited to petition against uses of patents that have an impact on access to health technologies. For instance, in 2005 the World Intellectual Property Organization (WIPO) stated that 'under no circumstances can human rights ... be subordinated to intellectual property protection'. ${ }^{53}$ In 2004, the UN Special Rapporteur on the right to the highest attainable standard of health recommended that states promote 'intellectual property legislation consistent with human rights obligations ${ }^{54}$ and that ' $[\mathrm{p}]$ atent-holding pharmaceutical companies have a responsibility to ensure that their policies and practices do not negatively impact access to lifesaving medicines'. ${ }^{55}$ More recently, in March 2021, the International Committee on Economic Social and Cultural Rights stated that: ${ }^{56}$

[b] usiness entities ... have specific responsibilities to enable the realization of the right to health, including in relation to access to medicines and vaccines. ${ }^{57} \ldots$ [B] usiness entities should also refrain from invoking intellectual property rights in a manner that is inconsistent with the right of every person to access a safe and effective vaccine for Covid-19 or to the right of States to exercise TRIPS flexibilities. ${ }^{58}$

However, relying on human rights to encourage corporate entities to alter behaviour has had limited effect to date and, in practice, human rights have acted as a limited counterbalance to the prioritisation of financial considerations by corporate entities acting as rightsholders in this context. ${ }^{59}$ This has happened for two main reasons.

First, companies who hold intellectual property rights can exercise those rights as part of a broader right to property. ${ }^{60}$ As Brown has argued, such a right to property would allow companies to enjoy this right without sharing it. ${ }^{61}$ Thus, claims that a right to health is being encroached upon or affected by how patents are used result in a conflict between two rights - the right to health, and the right to property. Whilst any conflict of rights would require a balancing of rights approach, ${ }^{62}$ interference with the

\footnotetext{
${ }^{52}$ See in particular, UDHR, Art 25 and International Covenant on Economic, Social and Cultural Rights, Art 12.

${ }^{53} \mathrm{WIPO}$ 'Proposal to establish a development agenda for WIPO: an elaboration of issues raised in document' (WO/GA/31/ 11) (6 April 2005) [51], available at https://www.wipo.int/edocs/mdocs/mdocs/en/iim_1/iim_1_4.pdf.

${ }^{54}$ United Nations The Right of Everyone to the Enjoyment of the Highest Attainable Standard of Physical and Mental Health (Report of the Special Rapporteur, Paul Hunt Addendum Mission to the World Trade Organization, 1 March 2004 ) p 21.

${ }^{55} \mathrm{~J}-\mathrm{Y}$ Lee and $\mathrm{P}$ Hunt 'Human rights responsibilities of pharmaceutical companies in relation to access to medicines' (2012) 40(2) Journal of Law, Medicine and Ethics 220 at 228.

${ }^{56}$ Committee on Economic, Social and Cultural Rights 'Statement on universal affordable vaccination for Covid-19, international cooperation and intellectual property' E/C.12/2021/1.

${ }^{57}$ See CESCR General Comment No 14 (2000) on the right to the highest attainable standard of health, para 42.

${ }^{58}$ See Principles $26-28$ of the 'Human rights guidelines for pharmaceutical companies in relation to access to medicines', incorporated in the report to the General Assembly of the UN Special Rapporteur on the right to the highest attainable standard of health, A/63/263, 11 August 2008.

${ }^{59}$ This paper focuses specifically on how change could be delivered within the confines, and the inherent limitations of the current system. In making such arguments, this paper is not suggesting that companies should not seek to align their decision-making with broader human rights considerations. Nor are we suggesting that the system for the enforcement of human rights should not be amended or strengthened in this context. However, such issues are beyond the scope of the current paper. Instead, here we are reflecting on the limitations of the current existing system under which any imposition of human rights obligations on corporate entities lacks teeth. In this paper, therefore, we are seeking to leverage shareholder action as one means to encourage change in this context.

${ }^{60}$ AEL Brown 'Socially responsible intellectual property: a solution?' (2005) 2(4) SCRIPT-ed 485.

${ }^{61}$ Ibid.

${ }^{62} \mathrm{~J}$ MacMillan 'Administrative law, commerce and human rights' in S Bottomley and D Kinley (eds) Commercial Law and Human Rights (Hampshire: Dartmouth Publishing Company, Ashgate Publishing, 2002) p 257.
} 
right to property is arguably often easier to prove and thus to protect in this context. This is because the scope of what is protected by a right to health can be nebulous in nature, and the way in which it is stated in international treaties gives 'great latitude amongst states in giving enforceable shape and form to this human right'. ${ }^{63}$ Moreover, even where access to health technologies is restricted, it may be difficult to demonstrate that this restriction is caused specifically by the use of a patent. As the patent right is time limited, it is sometimes argued that potential restrictions on access to health technologies attributable to patents are proportionate as they last for a limited period of time and they play a role in incentivising innovation. ${ }^{64}$ As a result, it can be easier to prove that there could be a potential interference with the right to property (if one was seeking to modify how rightsholders use patents over health technologies) than with the right to health in some contexts.

Secondly, there are issues with the enforcement of human rights obligations against companies. ${ }^{65}$ Ultimately, the primary obligation to protect and further human rights rests on states. ${ }^{66}$ Companies are generally not legally bound by international human rights treaties, nor are they accountable for a failure to uphold these standards. ${ }^{67}$ This gap between aspiration and enforcement of human rights is reflected in a number of international initiatives that have sought to draw human rights considerations into corporate activities. However, the codes and guidelines formulated by these initiatives are, ultimately, voluntary. ${ }^{68}$ The Organisation for Economic Co-operation and Development (OECD) Guidelines for Multinational Enterprises (the OECD Guidelines), for example, are recommendations from governments to multinational enterprises operating in or from those countries that have adopted the OECD Guidelines. ${ }^{69}$ They set out 'principles and standards for responsible business conduct in a global context consistent with applicable laws and internationally recognised standards'. ${ }^{70}$ These principles and standards include urging enterprises to engage with relevant stakeholders so as to allow their views to be taken into account in corporate decision-making ${ }^{71}$ and to grant licences for the use of intellectual property rights and technology on reasonable terms. ${ }^{72}$ While these OECD Guidelines aim to promote the positive contribution that multinational enterprises can make to economic, environmental and social progress worldwide, they are non-binding. Similarly, the UN Guiding Principles for Business and Human Rights (the UN Guiding Principles) seek to provide a global standard for addressing and preventing adverse human rights impacts linked to corporate activity. The UN Guiding Principles note the need for companies to not just comply with applicable laws, but also to respect human rights. ${ }^{73}$ Yet these UN Guiding Principles place the duty of investigation, punishing and redressing business-related human rights abuses on individual states on the basis of domestic legislative and regulatory frameworks. ${ }^{74}$ Centralised enforcement of these UN Guiding Principles against companies is, therefore, lacking within the current framework.

Seeking to use human rights challenges to rectify access to health issues where such access issues are at least in part attributable to the use of intellectual property rights by companies, therefore, lacks

\footnotetext{
${ }^{63}$ S Thambisetty 'Improving access to patented medicines: are human rights getting in the way?' (2018) 3 LSE Law, Society and Economy Working Papers.

${ }^{64}$ It is questionable whether intellectual property provides appropriate/sufficient incentives in many contexts, particularly for vaccines: see AS Rutschman 'The intellectual property of vaccines: takeaways from recent infectious disease outbreaks' (30 January 2020) Michigan Law Review Online.

${ }^{65}$ Brown, above n 60 .

${ }^{66} \mathrm{C}$ Timmermann and $\mathrm{H}$ van den Belt 'Intellectual property and global health: from corporate social responsibility to the access to knowledge movement' (2013) 34 Liverpool Law Review 47 at 57.

${ }^{67}$ Brown, above n 60, at 506.

${ }^{68} \mathrm{C}$ Pedamon 'Corporate social responsibility: a new approach to promoting integrity and responsibility' (2010) $31(6)$ Company Lawyer 172 at 175.

${ }^{69}$ OECD Guidelines for Multinational Enterprises (2011 edition).

${ }^{70}$ Ibid, foreword.

${ }^{71}$ Ibid, section IIA(14).

${ }^{72}$ Ibid, section IX(4).

${ }^{73}$ United Nations Guiding Principles on Business and Human Rights (HR/PUB/11/04, General Principles, 2011).

${ }^{74}$ Ibid, IIIA(25).
} 
teeth. Indeed, some have argued that attempts to use human rights to address issues around access to healthcare in the intellectual property context can be counterproductive. ${ }^{75}$

\section{(c) Compulsory licensing - exceptionalised in practice}

Given that human rights frameworks offer limited scope to encourage a change of corporate rightsholders' patent licensing behaviour, the main current avenue to interfere with rightsholders' uses of patents over health technologies is via internal flexibilities within patent law - a key one being compulsory licensing. ${ }^{76}$ Compulsory licenses are mechanisms through which a state can issue a licence without the rightsholder's consent, provided specific criteria apply. If a compulsory licence is granted it is subject to the payment of adequate remuneration to the rightsholders (thus, the patent right is not extinguished). As patents are national rights, the compulsory licence is granted at a national level by the relevant government and each licence is only applicable in the state within which it has been granted. As a result, compulsory licences in multiple states over a single patent would be needed when seeking to use the patented technology in more than one state.

Compulsory licences can be provided for in all WTO member states under the TRIPS Agreement as confirmed under Article 31 of that Agreement. However, as noted above, such licences are granted at the national level, and hence national laws must offer effective mechanisms to obtain such licences, and states must show willingness to utilise them. Traditionally, the use of compulsory licences has been limited, and uncertainty arose around the extent to which these licences could be used in public health contexts. As a result, the Doha Declaration clarified that the TRIPS Agreement did not prohibit states taking measures to promote public health and using TRIPS flexibilities ${ }^{77}$ - including compulsory licences - for public health purposes. Since the Doha Declaration, some low- and middle-income countries have used compulsory licences to address access to medicines issues. ${ }^{78}$ However, the use of such licences remains relatively uncommon in higher-income countries. ${ }^{79}$

The compulsory licensing system has several shortcomings that limit its effectiveness as a tool to guide patent licensing behaviour. ${ }^{80}$ A major shortcoming is a lack of state willingness to use such measures. In many cases this is due to a fear of backlash from other states, including the imposition of trade sanctions and/or a fear of industry backlash if a compulsory licence is issued. ${ }^{81}$ These pressures can be particularly acute with respect to patents over health technologies as industry lobbies tend to be strong within some states. Other shortcomings include a failure of many national legal frameworks to offer effective avenues for the use of compulsory licensing, a lack of clarity around the amount of remuneration payable to rightsholders for the use of such licences and additional regulatory protections in place for health technologies (such as marketing and data exclusivity protections in the EU) that make the approval and manufacture of generic pharmaceuticals difficult

\footnotetext{
${ }^{75}$ Thambisetty, above n 63 .

${ }^{76}$ In discussing how compulsory licensing provisions could be strengthened here and in Part 4 below, we are not suggesting that compulsory licensing is a suitable mechanism to address all access to health issues arising from use of intellectual property rights - indeed, in a pandemic context like Covid-19, as one of us has discussed elsewhere, compulsory licensing has significant limitations if the goal is clearing intellectual property obstacles around eg global vaccine access. Instead, in a pandemic context in the absence of voluntary sharing of intellectual property rights and relevant know-how, a waiver of intellectual property rights - as is currently being considered in the Covid-19 context - is preferable and needed. (see Thambisetty et al, above n 5). However, compulsory licences could nevertheless offer a useful mechanism for encouraging socially responsible use of licences in some contexts if used on a more systematic basis.

${ }^{77}$ Doha, para 4 states '.. the Agreement can and should be interpreted ... in a manner supportive of WTO Members' right to protect public health and, in particular, to promote access to medicines for all'.

${ }^{78}$ For a database detailing the uses of TRIPS flexibilities, see http://tripsflexibilities.medicineslawandpolicy.org/.

${ }^{79}$ For example, European Patent Academy Compulsory Licensing in Europe (December 2018).

${ }^{80}$ McMahon, above $\mathrm{n} 9$ and 17.

${ }^{81}$ McMahon. above n 17, at 177; S Tantivess et al Introducing Government Use of Patents on Essential Medicines in Thailand, 2006-2007: Policy Analysis with Key Lessons Learned and Recommendations (Nonthaburi: International Health Policy Program, Ministry of Public Health, 2008).
} 
even where a compulsory license is considered or issued. Together, these shortcomings pose significant practical obstacles to the use of compulsory licences and the use of such licensing is often viewed as an exceptional last resort measure. ${ }^{82}$ As a result, the current practice around compulsory licensing does not offer a sufficient check on rightsholders' licensing behaviour. ${ }^{83}$

Accordingly, when it comes to imposing checks on rightsholders' behaviour, the dominant shareholder theory model has traditionally focused on financially-motivated drivers; there has been limited teeth in arguments based on human rights related to shifting corporate behaviour around patent use and licensing, and an exceptionalised role for compulsory licensing. These factors culminate to foster a system that generally favours financial profits within corporate approaches to the licensing and use of patents, with limited counterbalances to shift corporate behaviour towards broader public health interests.

\section{Enlightened shareholder - scope for a more nuanced understanding of value?}

Having said this, the narrow focus on shareholder 'value' in the form of profit may be starting to shift. There are increasing examples of a push for change coming from within companies towards a contemporary 'enlightened shareholder' view. Such moves are not yet mainstream. However, if they continue and strengthen, they could lead to a wider conceptualisation of what is meant by shareholder value to incorporate shareholder interests beyond those that are purely financial and short-term in nature. This could lend greater support to the need to consider the broader effects of corporate decision-making on society. To demonstrate this, here in Part 3 we examine: (a) the enlightened shareholder model; and (b) recent examples of shareholders actively petitioning for public interest considerations within the licensing and enforcement of patents.

\section{(a) Enlightened shareholder model}

Pursuant to an enlightened shareholder model of corporate governance, the directors of a company must act in the best interests of the company's shareholders and in a way that maximises shareholder value. However, in achieving this goal, the directors may also consider the interests of other stakeholders. ${ }^{84}$ This is not a positive duty imposed on directors. Instead, it is an acknowledgement that when working in the shareholders' best interests, a variety of factors need to be considered. While the primary corporate relationship is still between the company and its shareholders, this relationship sits within a much wider 'sphere of social intercourse ${ }^{85}$ that must be considered. Rather than being presented as concerned only with the short-term profit margin of a company, therefore, shareholders are treated as increasingly 'enlightened' and long-term in their focus, and increasingly comfortable with the fact that social responsibility and financial returns are not mutually exclusive pursuits. Of course, this contemporary shareholder primacy model assumes that shareholders as a class are now concerned with factors beyond just short-term profits (something it is acknowledged will not be the case for all shareholders ${ }^{86}$ ). Nevertheless, it offers a more nuanced and flexible approach to corporate decision-making where directors can take a holistic approach to achieving long-term corporate value and meeting shareholder interests. ${ }^{87}$

This enlightened shareholder model is not new. Indeed, UK company law has reflected this more nuanced view of shareholder value for some time. Section 172(1) of the Companies Act 2006 (UK) acknowledges the ultimate duty of a company's directors to its shareholders when it imposes on directors a fiduciary duty to promote 'the success of the company for the benefit of its members as a whole [in a company that issues shares, its members will be its shareholders]'. However, in pursuit of this

\footnotetext{
${ }^{82}$ McMahon, above n 9.

${ }^{83}$ McMahon, above n 17.

${ }^{84}$ A Griffiths 'Trademarks and responsible capitalism' (2012) 43(7) IIC 798 at 805.

${ }^{85}$ Kuo and Means, above n 40, at 1003 .

${ }^{86}$ Yan, above n 8, at 1067.

${ }^{87}$ Stout, above n 46 , at 4 .
} 
success, directors may 'have regard' to a number of external factors, including the 'likely consequences of any decision in the long term', 88 'the need to foster the company's business relationships with suppliers, customers and others ${ }^{89}$ and 'the desirability of the company maintaining a reputation for high standards of business conduct'. ${ }^{90}$ In striving to promote the company's success for the benefit of its shareholders, therefore, directors may take into account such broader external drivers. ${ }^{91}$ The UK Corporate Governance Code (which applies to publicly-owned companies with a 'premium listing' ${ }^{92}$ in the UK, whether incorporated in the UK or not) similarly acknowledges that '[a] successful company is led by an effective and entrepreneurial board, whose role is to promote the long-term sustainable success of the company, generating value for shareholders and contributing to wider society. ${ }^{93}$ The OECD in its Principles of Corporate Governance has noted that while directors are accountable to, and must always act in the best interests of, a company and its shareholders, they are also expected to 'take due regard of, and deal fairly with' other stakeholders, and to observe environmental and social standards. ${ }^{94}$ These provisions restate the shareholder primacy model of corporate decision-making but, in doing so, they provide context on how company success and shareholder value can be achieved.

Section 172(1) of the Companies Act 2006, the UK Corporate Governance Code and the OECD's Principles of Corporate Governance do not oblige directors of companies within their remit to consider all stakeholder interests, nor do they permit directors to prioritise the particular interests of individual shareholders beyond those of the shareholders generally. Nevertheless, they reflect a growing recognition that a company's and its shareholders' long-term success are closely linked to a broader range of shareholder interests beyond merely financial issues. This reflects a wider trend in corporate practice. In the Davos Manifesto 2020, for example, the World Economic Forum called on companies to 'responsibly manage[] near-term, medium-term and long-term value creation in pursuit of sustainable shareholder returns that do not sacrifice the future for the present ${ }^{95}$ and advocated for a 'better kind of capitalism'. ${ }^{96}$ This echoes a pledge given by some of the world's largest companies at the 2019 G7 Leaders' Summit, which confirmed that 'inclusive growth drives long-term value creation, creating broad benefits for shareholders and other stakeholders alike,. ${ }^{97}$ Such statements are, of course, statements of purpose rather than binding undertakings. ${ }^{98}$ But they nevertheless represent a publicly articulated, business-focused recognition that company success and stakeholder engagement do not have to be mutually exclusive - a company's long-term success and achievement of value for its shareholders can involve a broad range of considerations.

\section{(b) Emergence of the engaged shareholders: actively petitioning for change}

The enlightened shareholder approach to corporate decision-making and calls for greater corporate responsibility would, therefore, appear to present a clear pathway for companies to adopt more socially responsible practices while still being able to pursue financial returns for shareholders. Yet this added

\footnotetext{
${ }^{88}$ Companies Act 2006, s 172(1)(a).

${ }^{89}$ Ibid, s $172(1)(c)$.

${ }^{90}$ Ibid, s $172(1)(\mathrm{e})$.

${ }^{91}$ House of Commons Trade and Industry Committee The White Paper on Modernising Company Law - Sixth Report of Session 2002-03 (HC 439) p 10.

${ }^{92}$ These are companies that comply with more onerous requirements than are required for a standard listing pursuant to the UK's Listing Rules.

${ }^{93}$ UK Corporate Governance Code 2018, s 1.

${ }^{94}$ OECD G20/OECD Principles of Corporate Governance (Paris: OECD Publishing, 2015) p 45.

${ }^{95} \mathrm{~K}$ Schwab 'Davos Manifesto 2020: the universal purpose of a company in the fourth industrial revolution' (2 December 2019), available at https://www.weforum.org/agenda/2019/12/davos-manifesto-2020-the-universal-purpose-of-a-companyin-the-fourth-industrial-revolution/.

${ }^{96}$ Ibid.

${ }^{97}$ Business for Inclusive Growth 'Business Pledge against Inequalities' OECD (23 August 2019), available at https://www. oecd.org/inclusive-growth/businessforinclusivegrowth/Business-Pledge-against-Inequalities.pdf.

${ }^{98}$ Bebchuk and Tallarita, above n 8 , at 130 .
} 
flexibility within the shareholder primacy model has not led to widespread overhaul of corporate decision-making to date. As discussed above, for example, companies have adopted a mixed approach to how they protect their intellectual property rights and the extent to which that protection reflects broader public health needs at stake.

A disconnect between aspirational guidance and corporate practice has in part come from a lack of incentive for directors to consider wider stakeholder interests. Bebchuk and Tallarita refer to the 'unrealistic expectations and hopes that corporate leaders will, on their own, deliver substantial protections to stakeholders'. ${ }^{99}$ We acknowledge that we cannot necessarily expect directors to expand their sphere of concern beyond shareholder financial returns of their own accord without that expansion being a consequence of internal or external pressures driving such change. Recently, however, there have been signs that this pressure could successfully come from within companies themselves. This is reflected in examples of shareholders actively petitioning companies to act in a more socially responsible manner. In such instances, shareholders are telling company directors what a company's priorities should include and in doing so they are framing their notion of value - such moves contribute to and reflect the potential for incremental development of a longer-term and more sustainable conception of shareholder value that incorporates broader considerations of the impact of corporate decisions for society more generally. The Covid-19 pandemic could, in our view, be the catalyst that propels this trend and encourages a more concerted move towards taking greater account of public health interests at stake in the patent licensing of health technologies.

In this context, engaged shareholders represent an embodiment of the 'enlightened shareholder', and place upward pressure on companies to engage with broader societal interest considerations. Such activism has most clearly been seen in public companies whose shares are listed on stock exchanges and whose ownership can rest with a diverse range of shareholders. For instance, in January 2021, a resolution ${ }^{100}$ by a group of 15 pension and investment funds and backed by 117 individual shareholders within the London headquartered HSBC Bank plc called for the bank to increase its climate commitments, including by reducing loans and underwriting services to clients relying heavily on the use of fossil fuels. ${ }^{101}$ This special resolution, which needed $75 \%$ of shareholders voting at the bank's annual general meeting to vote in favour, was approved in May 2021 by $99.71 \%$ of shareholders present and voting. ${ }^{102}$ The resolution was co-ordinated by ShareAction, a charity group focused on building a responsible finance system, whose aims include a demand for 'a legal framework that gives citizens' rights to information about where and how their assets are invested [and] is designed to achieve a virtuous circle in which people can see what happens to their money and become more engaged with the workings of the investment system'. ${ }^{103}$ In other words, seeking to increase the powers of shareholders in influencing how their investment in the company is being managed and encouraging shareholders to have a say in how corporate decisions affect issues of social importance. This resolution follows a similar resolution coordinated by ShareAction on behalf of shareholders in January 2020 taken by a shareholder group of 11 investment funds and pension funds, and signed by over 100 individual shareholders, calling for Barclays Bank UK plc (Barclays) to place clear targets on its lending and service provision to entities that rely heavily on fossil fuels. ${ }^{104}$ It also called on Barclays to phase out lending to companies in the energy sector whose activities are not aligned with the Paris Agreement climate accord. ${ }^{105}$ In that context, Daniel Wiseman, lawyer for Client Earth noted that:

\footnotetext{
${ }^{99}$ Ibid, at 171 .

${ }^{100}$ See resolution, available at https://shareaction.org/wp-content/uploads/2021/01/HSBC-resolution-wording.pdf.

${ }^{101} \mathrm{~K}$ Makortoff 'Shareholders push HSBC to cut exposure to fossil fuels' The Guardian (10 January 2021), available at https://www.theguardian.com/environment/2021/jan/10/shareholders-push-hsbc-to-cut-exposure-to-fossil-fuels.

${ }^{102}$ HSBC 'Shareholders back HSBC's net zero commitments' (28 May 2021), available at https://www.hsbc.com/news-andmedia/hsbc-news/shareholders-back-hsbcs-net-zero-commitments.

${ }^{103}$ See ShareAction website, available at https://shareaction.org/about-us/.

${ }^{104}$ Makortoff, above n 101.

${ }^{105} \mathrm{~W}$ Kuhn 'We've filed a climate resolution at Barclays - now it's time for investors to back it' ShareAction (8 January 2020), available at https://shareaction.org/weve-filed-a-climate-resolution-at-barclays/.
} 
[w] ith this resolution, Barclays has taken positive action on climate. The resolutions now before shareholders present an historic opportunity to transform Barclays from an industry laggard to a global leader on climate. They show why it is so critical that investors flex their stewardship muscles and demand action. ${ }^{106}$

This conceptualisation of shareholders as 'stewards' and the attempt to use shareholder power to foster responsible corporate decision-making is a change from a conception of a shareholder concerned solely with short-term financial returns. Such moves, if they continue and strengthen over time, could help to influence a change in corporate behaviour. For instance, in the case of Barclays, the January 2020 resolution was voted on in May 2020 by shareholders and supported by $24 \%$ of those shareholders. While this was not sufficient for it to pass, Barclays was still required to respond to the resolution as over $20 \%$ of the shareholders had voted in favour of it. Subsequently, Barclays developed a new climate policy, and as part of this policy the bank has sought to bring its lending in line with the Paris Agreement and has committed to net zero by $2050 .{ }^{107}$ This move demonstrates the leverage shareholders can have to seek changes in company policies to account for broader stakeholder interests. ${ }^{108}$ As shareholders increasingly lend their voices to encouraging corporate decision-making to align with broader societal concerns, this could support the re-conceptualisation of what falls within shareholder 'value' under the shareholder primacy model. ${ }^{109}$ These shareholders are not simply assuming that company directors will voluntarily engage with social issues - they are explicitly calling on them to do so.

The environment, climate change and green issues have been a focus of shareholder engagement to date. However, broader social issues, including health-related ones, are increasingly being placed on corporate agendas by shareholders. In February 2021, for example, institutional and retail investors of Tesco plc (Tesco) (the UK-based supermarket chain) filed a shareholder resolution calling on Tesco to set targets to increase the proportion of healthy products in its sales. ${ }^{110}$ There are also examples of shareholders in the healthcare sector specifically aligning with an actively engaged shareholder trend and calling on companies to consider social responsibilities with respect to distribution of, and access to, health technologies. For example, in April 2020 over 40 shareholders with collective global assets of over $€ 1.9$ billion called on pharmaceutical companies - including Gilead, Johnson \& Johnson and Roche - to work to combat the Covid-19 pandemic. This call was led by the Achmea Investment Management. The group developed an Investor Statement that included a focus on ensuring global access to health technologies for Covid-19. ${ }^{11}$ The group called for short-term financial considerations to take 'second place' and instead for there to be a concerted focus on ending the pandemic. Achmea's press release stated that:

[t]he asset managers and pension funds note that the pharmaceutical industry has launched several initiatives to curb the coronavirus. Unfortunately, at the same time, they have seen

\footnotetext{
${ }^{106}$ ClientEarth Communications 'Responding to investor pressure, Barclays presents new, beefed up climate policy' ClientEarth (6 April 2020), available at https://www.clientearth.org/latest/latest-updates/news/responding-to-investorpressure-barclays-presents-new-beefed-up-climate-policy/ (emphasis added).

${ }^{107} \mathrm{MC}$ Joy 'Shareholders approve Barclays' climate policy, rejects investor group resolution' S\&P Global (8 May 2020), available at https://www.spglobal.com/marketintelligence/en/news-insights/latest-news-headlines/shareholders-approve-barclays-climate-policy-rejects-investor-group-resolution-58509498.

${ }^{108}$ ClientEarth Communications, above n 106.

${ }^{109}$ In 2021, BlackRock, the world's biggest investor and shareholder in multiple companies, stated that all companies in which BlackRock invests will be expected to disclose direct emissions from operations and from energy that they buy. See J Jolly and J Ambrose 'Oil firms should disclose carbon output, says BlackRock' The Guardian (17 February 2021), available at https://www.theguardian.com/business/2021/feb/17/oil-firms-should-disclose-carbon-output-says-blackrock.

${ }^{110}$ ShareAction 'Tesco faces shareholder challenge over its role in UK obesity crisis' (10 February 2021), available at https:// shareaction.org/tesco-faces-shareholder-challenge-over-its-role-in-uk-obesity-crisis/.

${ }^{111}$ Achmea 'Asset managers, pension funds and insurers call for international co-operation within the pharmaceutical industry to combat coronavirus' (16 April 2020), available at https://www.statnews.com/wp-content/uploads/2020/04/pressrelease-achmeaim-1.pdf.
} 
some examples of priority being given to short-term financial and competitive considerations, and this hinders the optimal action against the virus. This group of engaged shareholders believes that right now financial considerations should take second place in the global challenge of getting the coronavirus under control as quickly as possible. ${ }^{112}$

This is a clear statement by shareholders calling for public health needs to drive corporate decision-making. Moreover, the group explicitly called for a change in how patents were used in this context, stating that:

[t] he negative societal and financial impact of the Covid-19 crisis is unprecedented and needs to be resolved soon. Enforcing patents, excessive price setting, not disclosing relevant findings or securing extended market exclusivity through, for example, orphan drug designation should not run counter to this responsibility. ${ }^{113}$

These shareholders are reframing their interests as encompassing more than short-term financial returns. They are then seeking to use their influence to exert upward pressure on companies to help bring the pandemic under control. In this vein, Bianca Tetteroo, who was then the vice-chair of Achmea's Executive Board, stated that:

[a]s an engaged shareholder, we are always in dialogue with the companies we invest in and we now want to use our influence to combat this crisis that is affecting us all ... Through the Investor Statement and follow-up talks, we are calling for international co-operation among pharmaceutical companies. ${ }^{114}$

The group of shareholders has also suggested that it would be closely monitoring the pharmaceutical companies in which its members are invested and was 'calling for maximum transparency'. In particular, the group has noted that 'additional attention will be paid to this during shareholders' meetings and as part of normal engagement processes'. ${ }^{115}$

Shareholder activity in the healthcare context has not been confined to this one case. Other examples are becoming evident. In the US, in December 2020, the Interfaith Center on Corporate Responsibility (ICCR) announced that shareholders had filed resolutions with six pharmaceutical companies (Eli Lilly, Gilead, Johnson \& Johnson, Merck, Pfizer and Regeneron) requesting reports on 'whether and how [the company's] receipt of public financial support for development and manufacture of preventives and/or therapeutics for Covid-19 is being, or will be, taken into account when making decisions that affect access to such products, such as setting prices'. ${ }^{116}$ Such resolutions were designed as part of a longer-term strategy by these shareholders to promote accessibility and affordability of Covid-19 health technologies, ${ }^{117}$ and followed on from letters sent by the group to pharmaceutical companies in August 2020 requesting similar information. ${ }^{118}$ Again, the role of patents in this context was directly acknowledged by statements of the group. ${ }^{119}$ In particular, Meg Jones-Monteiro, ICCR's Program Director for Health Equity, noted:

\footnotetext{
${ }^{112}$ Ibid (emphasis added).

${ }^{113}$ Ibid.

${ }^{114}$ Ibid (emphasis added).

${ }^{115}$ Ibid.

${ }^{116}$ J Wokaty 'Shareholders press pharma companies accepting public funds to prioritize access and affordability in the development of Covid medicine' Interfaith Center on Corporate Responsibility ICCR (1 December 2020), available at https://www.iccr.org/shareholders-press-pharma-companies-accepting-public-funds-prioritize-access-and-affordability.

${ }^{117}$ See also L Moyer 'Activist shareholders press Pfizer, J\&J, and other pharma companies on Covid vaccine price and access' Barron's (1 December 2020), available at https://www.barrons.com/articles/activist-shareholders-press-pfizer-j-jand-others-on-covid-vaccine-price-access-51606842249.

${ }^{118}$ Wokaty, above n 116.

${ }^{119}$ See also Moyer, above n 117.
} 
[w] e want to ensure that any medical breakthroughs derived from the public's contribution will be priced in an accessible way so that communities of all income levels will benefit equally. The sharing of IP through a patent pool should, therefore, be a core strategy to help reduce price, increase overall supply and ensure universal access. ${ }^{120}$

Requests by shareholders for information on drug pricing have also, in some cases, sought to challenge high pricing on the basis that it could lead to reputational harm for companies, and 'credibility risks' related to public concern over the price of health technologies. ${ }^{121}$ For example, Oxfam America called for Johnson \& Johnson to ensure that its Compensation and Benefits Committee would 'report annually to shareholders on the extent to which risks related to public concern over drug pricing strategies are integrated into JNJ's incentive compensation policies, plans and programs ... for senior executives.' ${ }^{22}$

Shareholders are, therefore, increasingly petitioning for changes in rightsholders' behaviour, in a manner that considers broader public interests in ending the pandemic and facilitating access to healthcare. ${ }^{123}$ This direct shareholder activism with respect to corporate governance and decisionmaking of companies in the healthcare sector reflects an acknowledgment that protecting shareholder interests and honouring shareholder primacy can include meeting a company's broader stakeholder responsibilities. ${ }^{124}$ Some companies in the healthcare sector have pushed back on attempts by shareholders to advocate for social justice considerations. ${ }^{125}$ For instance, in February 2021, it was reported that Johnson \& Johnson and Pfizer were urging the Securities and Exchange Commission in the US to delay the shareholder resolutions discussed above requiring them to disclose pricing policies for Covid-19 vaccines, ${ }^{126}$ and at the time of writing, ${ }^{127}$ it remains to be seen how this will evolve. However, it is questionable how long companies will be able to push back if this engaged shareholder trend continues and more shareholders ask for such considerations to be accounted for.

In the UK, at AstraZeneca's annual general meeting in May 2021, investor activity focused on executive pay rather than on vaccine access issues. However, AstraZeneca can be contrasted with some US-based pharmaceutical companies as the company has initially pledged not to make a profit from the Covid-19 vaccine during the pandemic. ${ }^{128}$ Nevertheless this focus on executive pay by investors, together with other examples of shareholder activity discussed above, suggest that engaged shareholders are also an increasingly visible force in the UK corporate decision-making context. Going forward, this could be used to increase upward pressure within companies from shareholders calling for a reconceptionalisation of corporate decision-making to encapsulate a broader range of interests. As the Covid-19 pandemic continues, concerns with respect to equitable access to, and delivery of,

\footnotetext{
${ }^{120}$ Wokaty, above n 116 (emphasis added).

${ }^{121} \mathrm{~J}$ Woleben and M Gibney 'Pharma shareholders see risk in pricing, lack of independent chairmen' S\&P Global (11 April 2019), available at https://www.spglobal.com/marketintelligence/en/news-insights/latest-news-headlines/pharma-shareholders-see-risk-in-pricing-lack-of-independent-chairmen-51107867.

${ }^{122}$ Ibid.

${ }^{123}$ Moyer, above n 117.

${ }^{124}$ Ibid.

${ }^{125}$ Ibid.

${ }^{126} \mathrm{~K}$ Dunleavy 'Pfizer, Johnson \& Johnson balk at shareholders' push for Covid-19 vaccine pricing info' Fierce Pharma (3 February 2021), available at https://www.fiercepharma.com/pharma/pfizer-johnson-johnson-balk-at-shareholder-requestsfor-vaccine-pricing-info.

${ }^{127}$ June 2021.

${ }^{128}$ There are limits to this pledge by AstraZeneca which raise considerable concerns, as discussed by L McDonagh 'Oxford University has a special responsibility to ensure jabs reach the Global South' LSE Blog (28 April 2021), available at https:// blogs.lse.ac.uk/covid19/2021/04/28/oxford-university-has-a-special-responsibility-to-ensure-jabs-reach-the-global-south/. See also DP Mancini 'AstraZeneca vaccine document shows limit of no-profit pledge' Financial Times (7 October 2020), available at https://www.ft.com/content/c474f9e1-8807-4e57-9c79-6f4af145b686.
} 
health technologies may increase and intensify calls by shareholders across jurisdictions for companies to consider their responsibilities to a broader stakeholder base. ${ }^{129}$

\section{Supporting the engaged shareholder}

The engaged shareholder presents hope that companies may be encouraged to incorporate broader public interest considerations into their use and licensing of patents over health technologies.

We acknowledge that calls for greater social awareness from some individual shareholders on their own are unlikely to be a sufficient influence to drive change in corporate behaviour, and indeed that company directors may be concerned about backlash from other shareholders if they prioritise societal interests above short-term profits. ${ }^{130}$ However, we argue that the engaged shareholder's role can (and indeed should) be supported by broader strategies that encourage more shareholders to petition companies in this context, that provide a justification and lever for company directors to respond to such petitions, and that create a systemic acceptance of the need to give account to public interest considerations within the licensing of patented health technologies. In this context, we propose strategies that both incentivise and mandate more socially responsible uses of patents by rightsholders. Using a 'carrot and stick' approach we seek to encourage shareholders to call on company directors to license and enforce patents in a socially responsible way that aligns with broader public interests at stake, and to give those directors further business-oriented incentives for doing so.

With an increased focus on access to patented health technologies in the wake of Covid-19, we believe that now is an opportune time to bolster engaged shareholders' activities in this context. Taking a pragmatic approach, we seek to leverage and reform strategies that are already available, ${ }^{131}$ but which need to be adopted in a more systematic manner as part of a broader strategy of harnessing the power and voice of engaged shareholders. We suggest that four such strategies - encompassing societal, legal and business factors - could be used to encourage and foster more socially responsible uses of patents in the healthcare context, namely through: (a) harnessing reputational drivers by increasing public awareness of the impact that patent licensing and use can have on access to, and delivery of, healthcare; (b) encouraging ethical investment and investors to scrutinise how health technologies are licensed by increasing transparency around patent licensing; (c) encouraging greater recourse to compulsory licensing by states where needed for public health; and (d) normalising the use of contractual conditions in public funding of health research that ensure the accessibility of downstream health technologies developed using that funding.

Together these strategies do not simply leave socially responsible activity as a 'nice to have' at the discretion of corporate rightsholders' directors - rather, they seek to bring it forward into public and investor discourse, they seek to facilitate systemic change and increase scrutiny of corporate practices around patent use and licensing, and they aim to make avoidance of socially responsible licensing practices an unfavourable option for companies and their directors. Such strategies work together to encourage shareholder engagement and to support calls by shareholders for the implementation of more socially responsible licensing practices by rightsholders. They aim to provide the carrots and sticks that could make the engaged shareholder a more influential force in the healthcare context.

\section{(a) Public awareness: an incentivising strategy to leverage reputational factors}

First, it is important to increase public awareness of access to health issues, the role of patent rights in such contexts, the power that companies have in using patents, and how this can affect access to, and

\footnotetext{
${ }^{129}$ Shearman \& Sterling 'Effects of Covid-19 on shareholder activism and M\&A: views from corporate boards and the market' (October 2020), available at https://boardmember.com/wp-content/uploads/2020/10/Effects-of-Covid-19-onShareholder-Activism-and-MA-2.pdf.

${ }^{130} \mathrm{M}$ Yan 'Corporate social responsibility versus shareholder value maximization: through the lens of hard and soft law' (2019) 40(1) Northwestern Journal of International Law \& Business 47.

${ }^{131}$ For an overview of the debate surrounding the interaction between shareholder voting and a company's engagement with socially responsible activity see Yan, above $n 8$.
} 
delivery of, healthcare. To achieve this awareness, educational campaigns informing the public of the role of patents and how patents are used, as well as information for shareholders on the role that they can play in influencing this use, are a vital tool.

In this context, external reputational factors provide a strong, shareholder-oriented financial value justification for more socially responsible licensing practices that encourage patent-holding companies to go beyond the minimum that is legally required of them in terms of using and licensing patents. With companies subject to growing public scrutiny, ${ }^{132}$ corporate inaction in the face of a societal issue or crisis, or corporate action that is viewed by the public as contrary to societal wellbeing, could result in public backlash and lasting reputational damage. ${ }^{133}$ In the context of a health crisis affecting entire regions or even countries, the impact of negative publicity for companies could be particularly acute. ${ }^{134}$ As demonstrated in Part 2 above, during the Covid-19 pandemic the legal challenge by Labrador against a patent infringement by BioFire was withdrawn following public criticism after it emerged that BioFire was developing Covid-19 testing kits. ${ }^{135}$

A company's reputation and goodwill are valuable assets that must be protected if the company is to succeed in the long term. ${ }^{136}$ Growing public awareness of access to health issues and the relevance of patents and other intellectual property rights could result in companies suffering reputational damage if they are seen as licensing, using or enforcing such rights in a manner that conflicts with public health needs. Such reputational damage could result in negative publicity, a loss of stakeholder trust (including with regulators), distancing by customers and suppliers, a closure of potential new markets, and ultimately, adverse financial consequences for the company and a negative impact on shareholder financial value. ${ }^{137}$ Even if there is a perceived risk to short-term profits by licensing patented health technologies in a more socially responsible manner, therefore, there would be a commercial incentive (alongside a moral one) in doing so. Thus, mobilising and focusing public awareness can act as a strong driver to incentivise socially responsible patent licensing and enforcement behaviours. Moreover, by pursuing corporate activities that actively address societal issues and consider the interests of a broad sphere of stakeholders, company directors can seek to reduce the extent to which corporate (in)action could damage the company's reputation. In this way, companies in the healthcare sector can be encouraged to pursue socially responsible licensing practices by using reputational risk as a key driver for corporate behaviour. ${ }^{138}$

Public pressure could also directly focus and support the actions of engaged shareholders and, in doing so, embed the expectation that shareholders will demand more socially responsible licensing practices from the health-care companies in which they invest. If the public is more aware of how companies use and license patents over health technologies, and if public backlash arises where such patents are used in a manner that conflicts with broader public health interests, this could act as a catalyst for more shareholders to petition for action. Shareholders could, therefore, be motivated by similar public interest aims, or, particularly in the corporate shareholder context, by a fear that they themselves could also come under public scrutiny for the company's behaviour.

\section{(b) Market expectations: an incentivising strategy to leverage ethical investment}

An increasingly prominent factor driving corporate decisions is the growth in ethical investment practices whereby investors choose to invest in companies that meet benchmarks of sustainability and

\footnotetext{
${ }^{132}$ European Commission European Competitiveness Report 2008 (COM, 2008) 774 [4.2]; Griffiths, above n 84, at 804.

${ }^{133}$ The Economist 'Just good business' (2008) 386(8563) Special Report 3.

${ }^{134}$ Moyer, above n 117.

${ }^{135} \mathrm{~F}$ Tietze et al 'Crisis-critical intellectual property: findings from the Covid-19 pandemic' (2020) Centre for Technology Management (CMT) Working Paper Series, p 4.

${ }^{136}$ Griffiths, above $\mathrm{n} 84$, at 806 .

${ }^{137} \mathrm{H}$ Droppert and S Bennett 'Corporate social responsibility in global health: an exploratory study of multinational pharmaceutical firms' (2015) 11(15) Globalization and Health 4.

${ }^{138}$ HA Grossman 'Refining the role of the corporation: the impact of corporate social responsibility on shareholder primacy theory' (2005) 10(2) Deakin Law Review 572 at 581.
} 
social responsibility. Pursuing a more socially responsible approach to licensing and use of patents over health technologies could, therefore, be used to attract new investment into companies from investors who specifically target socially responsible investment opportunities. ${ }^{139}$ These investors could then themselves become shareholders within a company. For existing company shareholders who are petitioning for a company to acknowledge broader stakeholder considerations in its decisionmaking, an increase in the number of engaged shareholders pursuing similar social agendas could empower activism and strengthen the engaged shareholder voice within the company.

Increasingly, investors are taking a more holistic approach to determining a company's suitability for investment and are looking beyond short-term profits to how long-term value and sustainability are built into directors' decision-making. This environmental, social and governance (ESG) investing (sometimes referred to as socially responsible investing) targets companies displaying positive ESG behaviour. It is a market that grew to over US $\$ 30$ trillion in 2018, with further growth in 2019 and $2020 .{ }^{140}$ Investors deliberately taking ESG factors into account when considering making an investment have, therefore, become a visible category of investor in the global financial markets. ${ }^{141}$ Current growth of ESG investing has also been influenced by international industry networks, most notably the United Nations' Principles for Responsible Investment, under which investors commit to incorporating ESG issues into their investment activities. ${ }^{142}$

The concept of ESG is porous and influenced by the subjective ambitions of the investor. Nevertheless, certain themes have emerged. Global concerns over climate change have, up until recently, resulted in an emphasis on the 'environmental' aspects of a company's activities when determining the company's suitability for ESG investors. ${ }^{143}$ However, with the growth in multijurisdictional health and other social crises and concern for the wider social impact of company decisions, social concerns have come to prominence as an investment consideration. ${ }^{144}$ Companies involved in the healthcare sector whose activities focus on facilitating reasonable access to healthcare could, therefore, leverage these activities to encourage investment into the company. In this way, companies could be incentivised to pursue socially responsible use of patents over health technologies in order to encourage and maintain investment from socially aware investors.

Such trends could also be used to increase transparency in corporate activities and, in doing so, provide the engaged shareholder with information that can guide, inform and support their actions. In this context, disclosure of a company's socially responsible activities has traditionally been on a voluntary basis with industry disclosure frameworks seeking to encourage transparency and consistency amongst companies. The Global Reporting Initiative Sustainability Reporting Standards, for example, seek to establish a 'common language for organizations and stakeholders, with which the economic, environmental, and social impacts of organizations can be communicated and understood'. ${ }^{145}$

\footnotetext{
${ }^{139} \mathrm{M}$ Lee and J Kohler 'Benchmarking and transparency: incentives for the pharmaceutical industry's corporate social responsibility' (2010) 95 Journal of Business Ethics 641 at 652.

${ }^{140} \mathrm{P}$ Stevens 'Your complete guide to investing with a conscience, a $\$ 30$ trillion market just getting started' CNBC (14 December 2019), available at https://www.cnbc.com/2019/12/14/your-complete-guide-to-socially-responsible-investing. html; C Umunna 'ESG investing came of age in 2020 - millennials will continue to drive it in 2021', Forbes (18 December 2020), available at https://www.forbes.com/sites/chukaumunna/2020/12/18/esg-investing-came-of-age-in2020millennials-will-continue-to-drive-it-in-2021/?sh=35e8c461409a. Indeed, Deloitte has forecast that ESG-mandated assets could make up to half of all managed assets in the US by 2025: S Collins and K Sullivan 'Advancing environmental, social, and governance investing', Deloitte (20 February 2020) available at https://www2.deloitte.com/us/en/insights/industry/ financial-services/esg-investing-performance.html.

${ }^{141}$ Lee and Kohler, above n 139 , at 650.

${ }^{142}$ United Nations Principles of Responsible Investment, available at https://www.unpri.org/pri/what-are-the-principles-forresponsible-investment.

${ }^{143}$ J Neilan et al 'Time to rethink the S in ESG' Harvard Law School Forum on Corporate Governance (28 June 2020), available at https://corpgov.law.harvard.edu/2020/06/28/time-to-rethink-the-s-in-esg/.

${ }^{144}$ Ibid; A Mooney 'Coronavirus forces investor rethink on social issues' Financial Times (30 April 2020), available at https://www.ft.com/content/bc988e0e-687c-4c72-98eb-ae2595e29bee.

${ }^{145}$ Consolidated set of GRI Sustainability Reporting Standards, Introduction (GRI 101, 2020).
} 
These standards call on companies to disclose non-financial information, such as how a company has responded to its stakeholders' reasonable expectations and interests, and how the company has performed in the wider context of sustainability. ${ }^{146}$ The OECD's Principles of Corporate Governance similarly encourage companies to disclose non-financial performance including (where relevant to the company) relating to 'social issues, human rights and other public policy commitments'. ${ }^{147}$ However, in addition to voluntary disclosure frameworks, legislative and regulatory authorities are increasingly seeking to encourage ESG-related disclosure by integrating this disclosure into reporting requirements. This has resulted in a growing number of non-financial disclosure requirements being placed on companies, particularly on larger companies. In the UK, while company directors are not obliged to take into account the broader stakeholder considerations built into section 172 of the Companies Act 2006, large companies ${ }^{148}$ (that do not qualify as small ${ }^{149}$ or medium companies) ${ }^{150}$ must nevertheless prepare a strategic report that includes a statement describing how the company's directors have 'had regard to the matters set out in section 172(1)(a) to (f) when performing their duty under section $172 .{ }^{151}$ As part of the strategic report, companies with shares listed on a stock exchange must also include information about social, community and human rights issues that are relevant to the performance and position of the company, as well as information about any relevant company policies and their effectiveness.

Some commentators have suggested that prioritising stakeholder needs could result in directors becoming less accountable to shareholders and more insulated from oversight. ${ }^{152}$ However, we argue that recent moves to require greater disclosure about corporate activities is a development that could help to address this oversight issue and, as such, should continue and expand in scope. Now is the time for governments, regulators, and investors to actively require greater transparency amongst companies through 'clearly designed' ${ }^{153}$ reporting frameworks that require disclosure of their socially responsible actions. Through this push for transparency, patent-holding companies in the healthcare sector may also be encouraged to pursue more socially responsible licensing and use of patents due to the need to disclose this information publicly and the potential for scrutiny if they act in a manner that is adverse to public health. This would in turn work to support the activities of shareholders calling for greater social engagement by companies in which they have invested.

With the influence of public opinion and the expectation from investors that companies will be transparent in disclosing their activities, there would appear to be a number of factors that, if strengthened and strategically leveraged, could support engaged shareholders calling for companies to consider the broader public interests impacted by their decision-making. These strategies help to place socially responsible licensing as a legitimate expectation of the public, investors and shareholders. In the healthcare context, the impact of Covid-19 could further strengthen these factors and bring them together with an overlapping objective of facilitating greater access to patented health technologies.

\section{(c) Compulsory licensing: a strategy to leverage change and mandate licensing aligning with public health needs}

In addition to encouraging more socially responsible use of patents over health technologies, 'hard' or legally enforceable strategies that push a company towards adopting such practices should be strengthened.

\footnotetext{
${ }^{146} \mathrm{Ibid}$, Principles 1.1 and 1.2 .

${ }^{147}$ OECD G20/OECD Principles of Corporate Governance (Paris: OECD Publishing, 2015) p 38.

${ }^{148}$ Companies that meet at least two of the following criteria: turnover of more than $£ 36 \mathrm{~m}$; balance sheet total of more than $£ 18 \mathrm{~m}$; and more than 250 employees.

${ }^{149}$ Companies that meet at least two of the following conditions: annual turnover must be not more than $£ 10.2$ million; the balance sheet total must be not more than $£ 5.1$ million; and the average number of employees must be not more than 50 .

${ }^{150}$ Companies Act 2006, s 414CZA(2).

${ }^{151}$ Ibid, s 414CZA(1).

${ }^{152}$ Bebchuk and Tallarita, above n 8 .

${ }^{153}$ Yan, above n 130 , at 78 .
} 
In this vein, state interventions with licensing behaviour can be achieved by using compulsory licensing as discussed above. However, much greater normalisation of the use of compulsory licensing by WTO states is needed for this to act as an effective leverage over corporate decision-making. ${ }^{154}$ The system of compulsory licensing must be made more effective and normalised in practice such that where licensing is contrary to broader public health aims, compulsory licences will be issued to temper such issues in a more routine rather than exceptional manner. In practice, such a change would likely mean that where voluntary licensing negotiation strategies are not sufficient, compulsory licences could be a more effective (and more regularly employed) threat to encourage or (where needed) force rightsholders to license health technologies on more reasonable terms. Such compulsory licences allow a third party to use a patented technology without the rightsholder's permission under specific circumstances. Seeking to avoid a real threat of compulsory licensing and a loss of control could form a strong incentive for companies to adopt socially responsible licensing strategies as part of a companies' decision-making. ${ }^{155}$ Companies may, therefore, be more inclined to make decisions that align with ensuring reasonable access to patented health technologies. Such decisions would also be justified on an enlightened shareholder value basis as it would allow the company to retain a level of control over its intellectual property rights provided such rights are used in a manner that aligns with delivering access to health technologies in a socially responsible manner. Such an approach would support a more holistic and longer-term conception of value for shareholders where shareholders also focus on the broader public interests at stake.

Moreover, if the use of compulsory licences by states became a more normalised practice and the threat of loss of control in such instances became more credible, companies holding patents over health technologies may be more effectively encouraged to pre-emptively implement socially responsible licensing practices to avoid the threat of a compulsory licence being issued. Indeed, we already see evidence of companies changing patent licensing practices within the Covid-19 context. ${ }^{156}$ Since the Covid-19 pandemic outbreak a small number of patent-holding companies have agreed to voluntary licences for health technologies or have agreed not to enforce relevant patents in such contexts (often under specified conditions). ${ }^{157}$ For example, to address the shortage and need for increased access to ventilators during Covid-19, Medtronic plc (Medtronic) released a 'permissive license' setting out the design, manufacturing and related information, as well as the software needed, to manufacture ventilators. This provided a non-exclusive, royalty-free, world-wide licence 'to use, make, have made, manufacture, have manufactured, sell and have sold a ventilator' in response to Covid-19. ${ }^{158}$ However, unlike compulsory licensing, voluntary licences allow the patent-holding company to determine the conditions of such licences. This allows the company to retain control over its inventions and the use of its intellectual property while still seeking to address access to healthcare concerns. ${ }^{159}$ In its permissive licence, for example, Medtronic set out clear parameters within which the licence could be used. These included a time limit, a limitation on Medtronic's liability for any damage that occurs from ventilators manufactured under the permissive licence and a confirmation that Medtronic continues to own the material disclosed. ${ }^{160}$ Thus, even though such initiatives may result in some short-term financial detriment to companies by allowing others to

\footnotetext{
${ }^{154}$ McMahon, above n 17.

${ }^{155}$ For example, the share price dropped for companies such as Pfizer following the announcement of US support for a TRIPS waiver: J Kollewe 'Pharmaceutical firms' shares tumble after US plans patent waiver on Covid vaccines' The Guardian (6 May 2021), available at https:/www.theguardian.com/business/2021/may/06/pharmaceutical-firms-sharestumble-after-us-plans-for-patent-waiver-on-covid-vaccines.

${ }^{156} \mathrm{R}$ Lloyd 'No strings Covid-19 IP pledge initiative underlines delicate balance biopharma businesses must strike' IAM (30 March 2020), available at https://www.iam-media.com/copyright/new-patent-pledge-underlines-delicate-balancing-actcompanies-must-strike-in-covid-19.

${ }^{157}$ Tietze et al, above n 135 , p 5.

${ }^{158}$ Medtronic 'Permissive license - open ventilator files' (2020), available at https://www.medtronic.com/content/dam/ medtronic-com/global/Corporate/covid19/documents/permissive-license-open-ventilator.pdf.

${ }^{159}$ Ethical questions can still arise about the extent of control retained by a rightsholder over such health technologies depending on how the rightsholder chooses to use this, but such issues are beyond the scope of this current paper.

${ }^{160}$ Ibid.
} 
manufacture a patented health-technology, they allow those companies to retain control over the terms of usage of their patent and facilitate use of intellectual property in a manner than aligns with broader health interests in a health emergency context. If compulsory licensing provisions were more frequently used, more companies may prefer to issue similar licences on a voluntary basis on terms they can control, rather than have a compulsory licence issued against them. Accordingly, if compulsory licences were more frequently used, this or the threat of one being issued could act as strong leverage to encourage companies to license health technologies in a more socially responsible manner.

Nonetheless, to achieve this, states must ensure that they evaluate and reform national laws, where needed, to make them as effective as possible in facilitating the use of compulsory licensing. During Covid-19 some countries, including Germany, France and Canada, modified national laws to make the use of compulsory licensing more feasible in certain contexts. ${ }^{161}$ The pandemic could be the catalyst that encourages such changes to domestic laws on a wider scale. However, states need to affirm their willingness to use such compulsory measures, and obstacles that currently prevent the practical use of compulsory licences in many contexts (such as data exclusivity issues and issues around transferring knowledge and know-how ${ }^{162}$ ) need to be urgently addressed. Only then will compulsory licensing be a more viable and effective oversight mechanism over rightsholders' behaviour. ${ }^{163}$

\section{(d) Contractual clauses: a strategy to mandate socially responsible licensing practices for intellectual property derived from funded research}

Finally, contractual clauses could be inserted by funders of research in the health context to mandate that any intellectual property rights (including patent rights over health technologies) developed using such funds are offered on an accessible basis downstream. Alternatively, for example, such contractual clauses could require that the companies that obtained such funds would license the relevant health technologies to voluntary intellectual property pools for public health purposes. During Covid-19, civil society groups have argued that the extensive public funding of Covid-19 health research should have been accompanied by clauses mandating the sharing of intellectual property rights arising from such research for the duration of the pandemic. This sharing could be through a global voluntary licensing mechanism such as CTAP, or by non-enforcement of intellectual property rights. ${ }^{164}$ Through CTAP, the WHO sought to encourage governments and other funders to:

promote that all Covid-19 publicly-funded and donor-funded research outcomes are affordable, available and accessible to all on a global scale through appropriate provisions in funding agreements, and include specific provisions regarding accessibility to and affordability of resulting Covid-19 related health products through global non-exclusive voluntary licensing, transparency and, when necessary, other commitments to expand access by sharing, for example, other intellectual property rights, know-how and data. ${ }^{165}$

\footnotetext{
${ }^{161}$ See discussion J Enmon and G Shoebridge 'Covid-19 - patent rights in the time of a pandemic' Lexology (27 August 2020), available at https://www.lexology.com/library/detail.aspx?g=a992bce6-c3ab-41f4-9e30-1fa46861d6f1; A Houldsworth 'The key covid-19 compulsory licensing developments so far' IAM (7 April 2020), available at www.iam-media.com/coronavirus/the-key-covid-19-compulsory-licensing-developments-so-far.

${ }^{162}$ McMahon, above $\mathrm{n}$ 9; E 't Hoen 'European pharmaceutical legislation needs exceptions to data and market exclusivity to protect European patients from high drug prices' Medicines Law and Policy (21 May 2018), available at https://medicineslawandpolicy.org/2018/05/european-pharmaceutical-legislation-needs-exceptions-to-data-and-market-exclusivityto-protect-european-patients-from-high-drug-prices/.

${ }^{163}$ See discussion in $\mathrm{n} 76$ above.

${ }^{164} \mathrm{MSF}$ 'A letter from civil society to the European Commission: Investment in R\&D funding for Covid-19 to be conditional on access and affordability for all' (25 March 2020), available at https://msfaccess.org/letter-civil-society-europeancommission-investment-rd-funding-covid-19-be-conditional-access-and.

${ }^{165}$ WHO 'Solidarity call to action - making the response to Covid-19 a public common good' (2020), available at https:// www.who.int/emergencies/diseases/novel-coronavirus-2019/global-research-on-novel-coronavirus-2019-ncov/covid-19-technology-access-pool/solidarity-call-to-action/ (emphasis added).
} 
However, there has been limited adoption of such contractual clauses within funding agreements for Covid-19 to date. Where they have been used, such clauses often leave considerable discretion to rightsholders by encouraging rather than mandating socially responsible licensing. In particular, such clauses within funding agreements were not routinely used for Covid-19 related publicly-funded research in the UK or other countries. This has prompted calls for such clauses to be used more routinely in the future. ${ }^{166}$ Greater consideration should, therefore, be given to imposing such contractual clauses with respect to publicly funded health research to retain control over how the benefits from such research are accessed downstream and to ensure this becomes a routine practice for publicly funded research. The more emphasis that is placed on this globally, the greater the reputational fall-out that could result if research partners (including rightsholders) refuse to comply or engage with such conditionality within publicly funded research. Such clauses will be a matter of contractual negotiation, but an increased market practice for including them in funding agreements where possible, alongside greater transparency around funding agreements to ensure these are subject to public scrutiny, ${ }^{167}$ and a greater expectation amongst funders and those in receipt of funding that such contractual clauses will be used, could encourage greater focus on uses of patents over health technologies in a manner that aligns with broader health interests.

\section{Conclusion}

The default position in company law in much of the common law world remains that of shareholder primacy, and company directors have a legal duty to run companies with the goal of maximising shareholder value. However, the growing relevance of an enlightened shareholder model of corporate governance means that the notion of 'value' - and how this is achieved - has started to become more nuanced, and arguably could incorporate a broader range of societal and longer-term interests of shareholders.

With the recognition of avenues for bringing other considerations into corporate decisionmaking, ${ }^{168}$ we are beginning to see a greater prioritisation of corporate activity that considers the impact on a wider group of stakeholders, while still protecting shareholder interests. With this reframing of shareholder value has come the growing appreciation that companies can pursue broader societal goals alongside economic ones. This is particularly relevant in the health context given the significant implications patents over health technologies can have for access to healthcare.

Yet the existence of broader stakeholder concerns alone has traditionally not been enough to steer companies towards more socially responsible licensing practices. It is only through a combination of strategies - internal, external, voluntary and mandatory - that we will truly see a shift towards more socially responsible enforcement and licensing of patents over health technologies. These strategies seek to lend further internal and external drivers, and additional business-focused incentives for company directors to approach the licensing of patented health technologies in a more socially responsible manner. Companies and their directors must be incentivised (and in some cases mandated) to make this transition. This paper has argued that there may now be indications that these incentives and drivers are growing in strength, and an integral element of this lies in harnessing the influence that

\footnotetext{
${ }^{166}$ See European Commission 'Access to research results and IP in a public emergency' (22 June 2021), available at https:// ec.europa.eu/info/news/access-research-results-and-ip-public-emergency-2021-jun-03_en; K Walsh et al 'Intellectual property rights and access in crisis' (2021) 52 IIC 379; M Mazzucato 'Mission-oriented innovation policy: challenges and opportunities. UCL Institute for Innovation and Public Purpose' (2017) Working Paper; E t Hoen 'The $€ 7.4$ billion for Covid-19 product and vaccine development needs a few strings attached' (2020) Medicines Law and Policy, available at https://medicineslawandpolicy.org/2020/05/the-e-7-4-billion-for-covid-19-product-and-vaccine-development-needs-a-few-strings-

attached/. In the pandemic context, Human Rights Watch have called for conditions to be imposed by governments on publicly funding research for Covid-19 'requiring technology transfer, that is, recipients should share all IP, data, and other knowhow to enable mass manufacturing of successful vaccine candidates': see Human Rights Watch 'Whoever finds the vaccine must share it' (October 2020) available at https://www.hrw.org/node/376815/printable/print.

${ }^{167}$ For a discussion of the lack of transparency around such clauses see Human Rights Watch, ibid.

${ }^{168}$ Stout, above n 46 , at 3 .
} 
shareholders can exert from within the company, pushing companies to make more socially responsible decisions around the licensing of patented health technologies to address broader public interests at stake. Covid-19 may propel this change, as there is a growing realisation that equitable access to Covid-19 health technologies is both morally needed to address the vast inequity in access to health technologies that is arising globally, but also key to bringing the pandemic under control. Such access is, therefore, in everyone's interests - including shareholders.

Accordingly, we argue that this is the time to leverage strategies that can push and pull corporate activity towards greater social responsibility in the licensing of patents over health technologies - the engaged shareholder can be empowered, and corporate decision-making can be influenced through greater public awareness of the impact of patent use on access to healthcare. This can also be strengthened by an increased focus by investors on corporate disclosure and socially responsible practices in investment choices, by encouraging states to show greater willingness to use compulsory licensing and other TRIPS flexibilities where needed and useful to facilitate access to health technologies, and by encouraging a practice of adopting contractual clauses in funding agreements for healthcare to mandate reasonable sharing of downstream intellectual property, particularly during public health crises. In short, a corporate focus on developing a socially responsible approach to the licensing of patented health technologies does not undermine the established primacy of shareholder value. Indeed, we have seen indications of shareholders telling directors that this is exactly what they value. It is, therefore, simply a pragmatic acknowledgment that in achieving value, the notion of value must incorporate a far more nuanced and longer-term perspective of what is of value to shareholders. Companies must look beyond short-term profits in licensing of patented health technologies, engaging with a broader conception of value that accounts for the impact of corporate decisions on the broader public interests at stake.

Cite this article: McMahon A, Richardson E (2022). Patents, healthcare and engaged shareholders: a pathway to encourage socially responsible patent use? Legal Studies 42, 271-295. https://doi.org/10.1017/lst.2021.49 